\title{
日本薬局方における生薬の標準化
}

\author{
袴塚高志
}

\section{Standardization of Crude Drugs for the Japanese Pharmacopoeia}

\author{
Takashi Hakamatsuka \\ National Institute of Health Sciences, Division of Pharmacognosy, Phytochemistry \\ and Narcotics; 3-25-26 Tonomachi, Kawasaki-ku, Kawasaki 210-9501, Japan.
}

(Received November 29, 2019)

\begin{abstract}
The latest edition of the Japanese Pharmacopoeia (JP) is the second supplement to the 17th edition containing 324 herbal medicines, of which 176 are crude drugs and 35 are Kampo extracts. Although 148 prescription Kampo extracts are covered by national health insurance, only 35 are listed in the latest JP. However, the sales volume of these 35 Kampo extracts accounts for more than $70 \%$ of the total sales volume of Kampo products, as Kampo formulas with higher sales volumes are preferentially listed in the JP. The JP officially defines the origin and description of the listed crude drugs and Kampo extracts and elaborates on their limited values and testing methods. As crude drugs and Kampo extracts are derived from natural products and have the characteristics of traditional medicines, some degree of variation has been experienced during their long-term use, which is one of the crucial differences from chemical drugs. The Japanese Pharmacopoeia Committee on Crude Drugs promotes standardization of the JP by reflecting the actual Japanese market situation. This review explains the characteristics of natural and traditional medicines in crude drugrelated items, the JP drafting process and points to be noted, and the significance of listing in the JP.
\end{abstract}

Key words_ crude drug; herbal medicine; Kampo medicine; Japanese Pharmacopoeia; traditional medicine

\section{1. はじめに}

生薬は天然物に由来し，わが国の伝統医学（漢方 医学）に基づいて用いられる漢方製剤や漢方医学に 基づかない天然物医薬品 (生薬製剂)の原料であり, また，生薬単体（単味）でも医薬品として使用され る。日本薬局方（以下，日局）の生薬総則に，「医 薬品各条の生薬は, 動植物の薬用とする部分, 細胞 内容物, 分泌物, 抽出物又は鉱物など」, と規定さ れ，医薬品各条における「生薬等」のセクションに は, 第 17 改正第二追補（令和元年 6 月 28 日公示・ 同日施行）の時点で，生薬，漢方製剂及び生薬製剤 が 324 品目収載されている. 1,2) 本稿では，天然物の 特徴を勘案した生薬等の日局による標準化の実際と その意義についてまとめる.

国立医薬品食品衛生研究所生薬部（干210-9501 川崎市 川崎区殿町 3-25-26)

e-mail: thakama@nihs.go.jp

本総説は, 日本薬学会第 139 年会シンポジウムS22 で 発表した内容を中心に記述したものである.

\section{2. 天然物医薬品の特徵}

天然物医薬品の大きな特徵は，多成分系であるこ とと多様性を有するということである. 多様性はさ らに，1）天然物の本質としての多様性，2）伝統的 医薬品としての多様性と 3）国際的な多様性に分類 することができる.

2-1. 多成分系としての生薬医薬品各条に収 載される化学医薬品の多くは単一の有効成分 (原薬) から構成されるが, 生薬は数百から数千の多成分で 構成され，しかも，化学医薬品と比較して極めて低 含量である. 複数の生薬を配合して製造される漢方 製剂であれば，さらに多くの成分から構成されるこ とになる（Fig. 1). 生薬において有効性を示す活 性本体はしばしば複数存在し，しかもどの成分が活 性本体であるか明確にされているケースは多くな い. 天然物医薬品の分野では，多成分の集合体を総 体として有効成分と見なすため，個々の含有成分が 未解明の状態であることに大きな違和感はない。し かし，公定書において規格化するという作業におい ては，これらの天然物医薬品特有の性質を考慮し， 


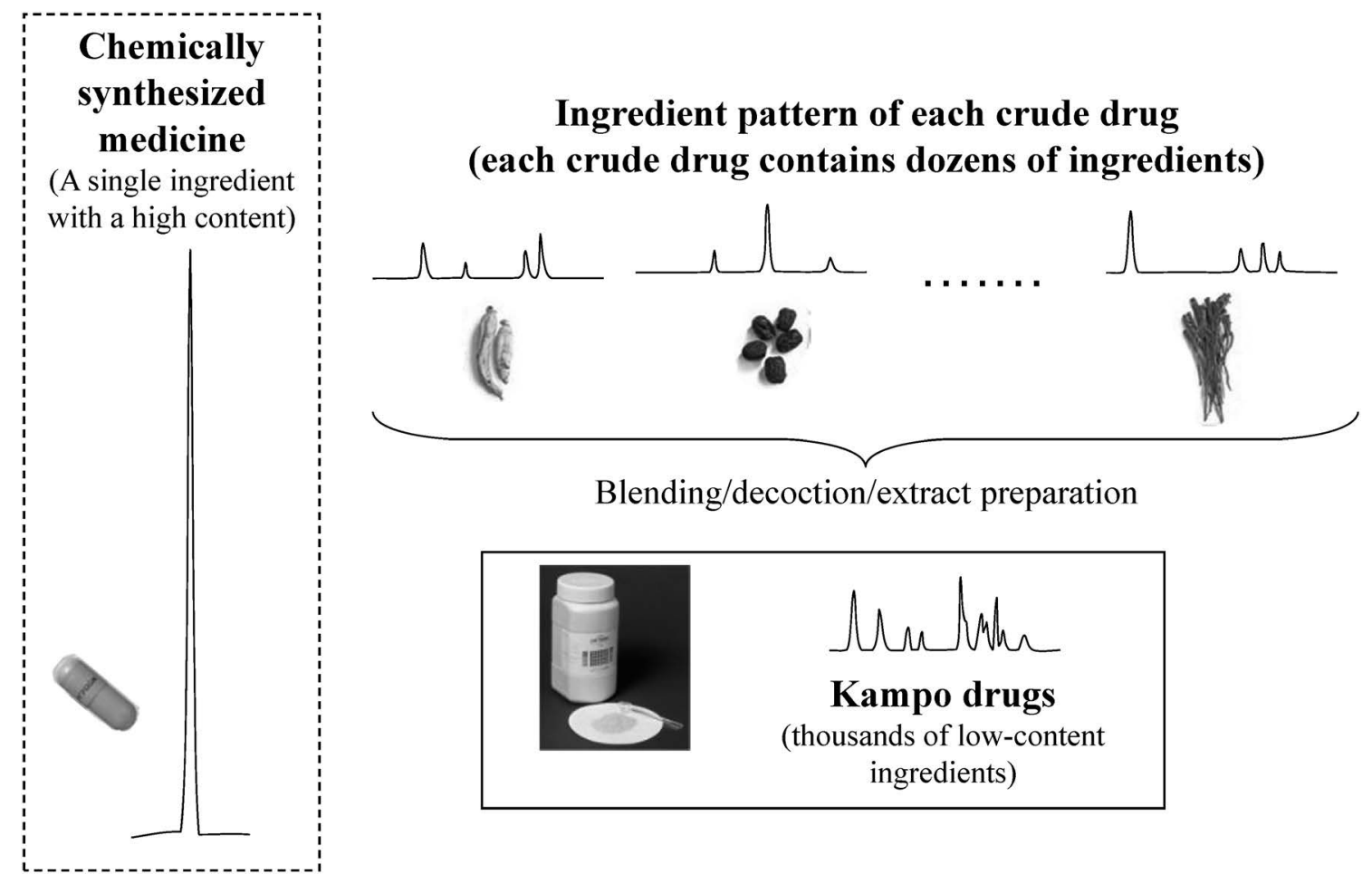

Fig. 1. Kampo Medicines as Multi-component Systems

化学医薬品と異なる考え方で取り組むことが必要と なる。

例えば，確認試験や定量法において，化学医薬品 の場合は活性本体の理化学的特性に基づいた赤外吸 収スペクトルや紫外可視吸収スペクトルで確認し， 活性本体そのものを定量することでよいが，多成分 系である生薬の場合は化学医薬品におけるこれらの 作法を適用することができない。 そこで生薬の場合 は，多くの成分の中から当該生薬を代表し得る「指 標成分」を選択し，その化合物を用いて確認試験や 定量法を行う。指標成分は，可能な限り当該生薬に 特徵的な有効成分が選ばれるべきであるが，低含量 の多成分系の中から目的成分を特異性高く検出でき る分析法を確立すること自体が簡単ではなく，そも そも有効成分が特定できていない場合もあるため, 特徵的でも有効性のマーカーでもなく，単に品質管 理に資するマーカーが指標成分として選ばれる場合 もある。、いずれにしても，生薬等を日局にて規格化 するにあたり確認試験や定量法を作成する際は，多 くの場合，化学医薬品の規格化では想定されていな い「指標成分の設定」という作業が発生し，同時に， 該当する指標成分を一般試験法の試薬・試液の項に 収載する作業も必要となる。 なお，定量法に用いる
指標成分は定量指標成分と呼ばれ，その設定の意義 等についての解説が日局参考情報に記載されている.

一方，化学合成することも天然より単離すること も難しく，あるいは，混合物の状態から単離してし まうと不安定となる性質を持つ等の理由により，指 標成分を市販可能な試薬として整備することが困難 な場合は，その指標成分を含有する生薬自体を試薬 として設定することもある．現在のところ「シャゼ ンシ」及び「ゴシツ」が薄層クロマトグラフィー (thin-layer chromatography; TLC) 用試薬として規 定され，それぞれ，生薬シャゼンシの確認試験，及 び，牛車腎気丸エキスに配合される生薬ゴシツの確 認試験において適用されている。ここでは，TLC 用試薬としての生薬より調製した標準溶液と, 被検 体である生薬あるいは漢方処方エキスから調製した 試験溶液の成分プロファイルを TLCにて比較し, 標準溶液由来の指標成分のスポットと色調及び $R \mathrm{f}$ 值が等しいスポットを試験溶液に検出することを もって確認する。

2-2. 天然物の本質としての生薬の多様性 天 然物の一般的な特質として，上述の多成分系である ことに加えて，多様性を持つことが挙げられる．特 に含有成分の多様性については顕著であり，同一種 


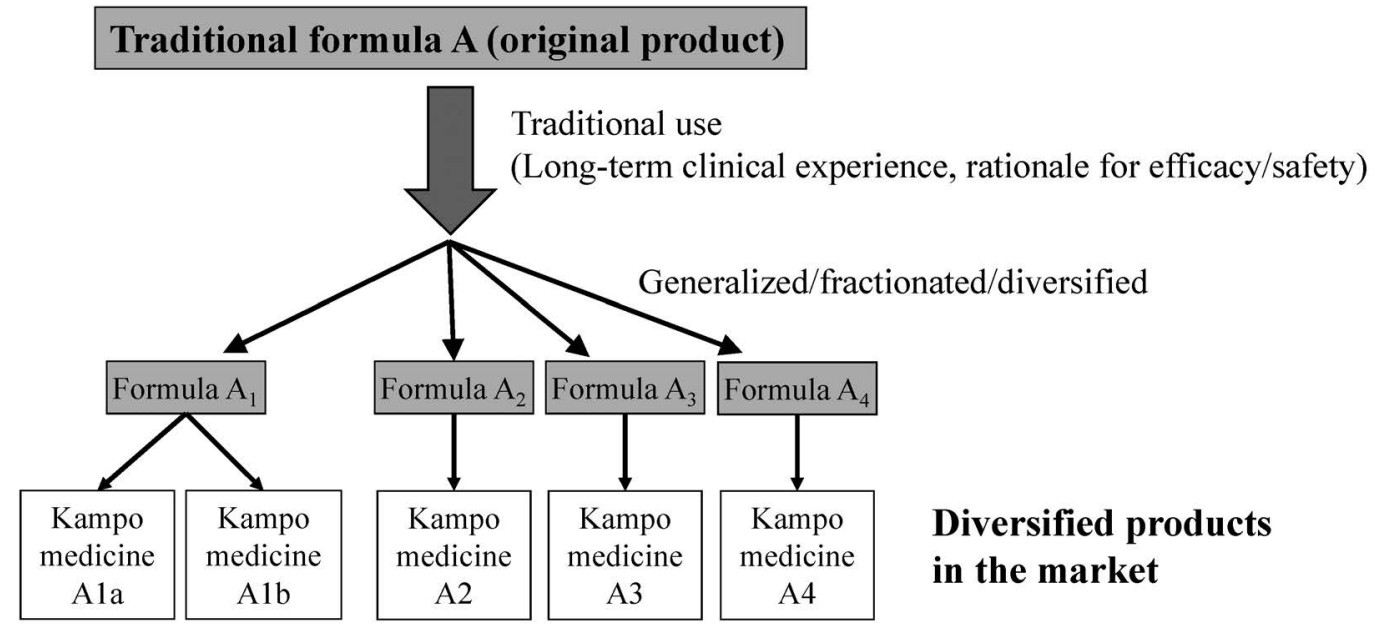

Fig. 2. Diversified Kampo Products during a Long-time Use in Japan

であっても成分の組成及び含量に多様性，つまりバ ラツキがある．多様性を生む要因は，基原動植物の 遺伝的要因, 土袞・気象等の環境的要因, 収穫時期 等の季節的要因，栽培条件，加工条件等である。同 じ天然物由来の果物で例えるならば，同じ品種のイ チゴであっても，一盛りの中に全く同じ形のイチゴ はなく，産地や天候や季節や生産年により形や味が 異なり，あるいは生産者の世話の具合により出来不 出来があることと同じである，このため，一般に日 局における生薬の成分含量規格は, 化学医薬品にみ られる狭い幅規格ではなく，「○○\%以上」「○○ $\mathrm{mg}$ 以上」という形で下限值が設定されている.た だし，ブシにおけるアコニチンアルカロイドのよう に，安全性に特に配慮すべき成分については上限も 設定されている，一方，製品では，医薬品としての 有効性及び安全性を確保するために，一定範囲内に 有効成分を収めることが特に考慮されるべきことか ら，最終製品に近い中間製剤の漢方処方エキスにお いては，定量指標成分の含量規格が 3-4 倍の幅で規 定されている. 3-4 倍の幅は化学医薬品の分野から みれば広いと感ずるものと思われるが，原料である 生薬における成分含量のバラツキが 10 倍を超える こともある天然物の特性を考慮するならば十分に制 御された規格幅と言える.

\section{2-3. 伝統的医薬品としての漢方製剤の多様性} わが国における天然物医薬品の多くは伝統的医薬 品である. したがって, 天然物医薬品に先発品・後 発品という考え方を当てはめることは難しく，敢え て探すとすれば古典に収載された処方が先発品に該
当することになり，一方，現在流通している製品は すべてが後発品ということになる．数百年あるいは 千年を超える歴史の中で，わが国の伝統医学である 漢方医学は国内に普遍化し，いくつかの流派に細分 化され，さらには同名の処方であっても流派毎に若 干の多様性が生じている，現代の漢方製剤メーカー は，いずれかの流派の処方内容に基づいて漢方製剤 の薬事承認を得ているため, 同名の漢方製剤であつ ても，原料生薬の配合割合がかならずしも同一では なく，ここに伝統的医薬品としての漢方製剤の多様 性が表出している（Fig. 2）。例えば，大型のド ラッグストアであれば，異なるメーカーの葛根湯が 並んで陳列され，原料生薬の組み合わせ（カッコ ン, マオウ, タイソウ, ケイヒ, シャクヤク, カン ゾウ, ショウキョウ）は同一であっても, 配合割合 の異なるものを見つけることができる，実際には， メーカー毎に原料生薬の仕入れ先が異なることも多 いため, 市場の最終製品は配合割合の違い以上の多 様性を包含していることになる.

\section{2-4. 天然物医薬品の国際的多様性 漢方医学} の源は古代中国医学であるが，奈良時代に伝来して 以来, 日本国内で数百年の年月を掛けて独自に発展 し，もはや中国医学とも韓国医学とも異なる医学体 系として成立している，疾患に関する考え方や治療 方針の立て方等について類似点も多いが，統一化・ 標準化することはもはや不可能と判断し得る程度に 独自性を有している。同じ東アジア地域に位置する ため，植生はよく似ており，生薬の原料となる基原 動植物は共通のものも多いが，それぞれの国に特有 


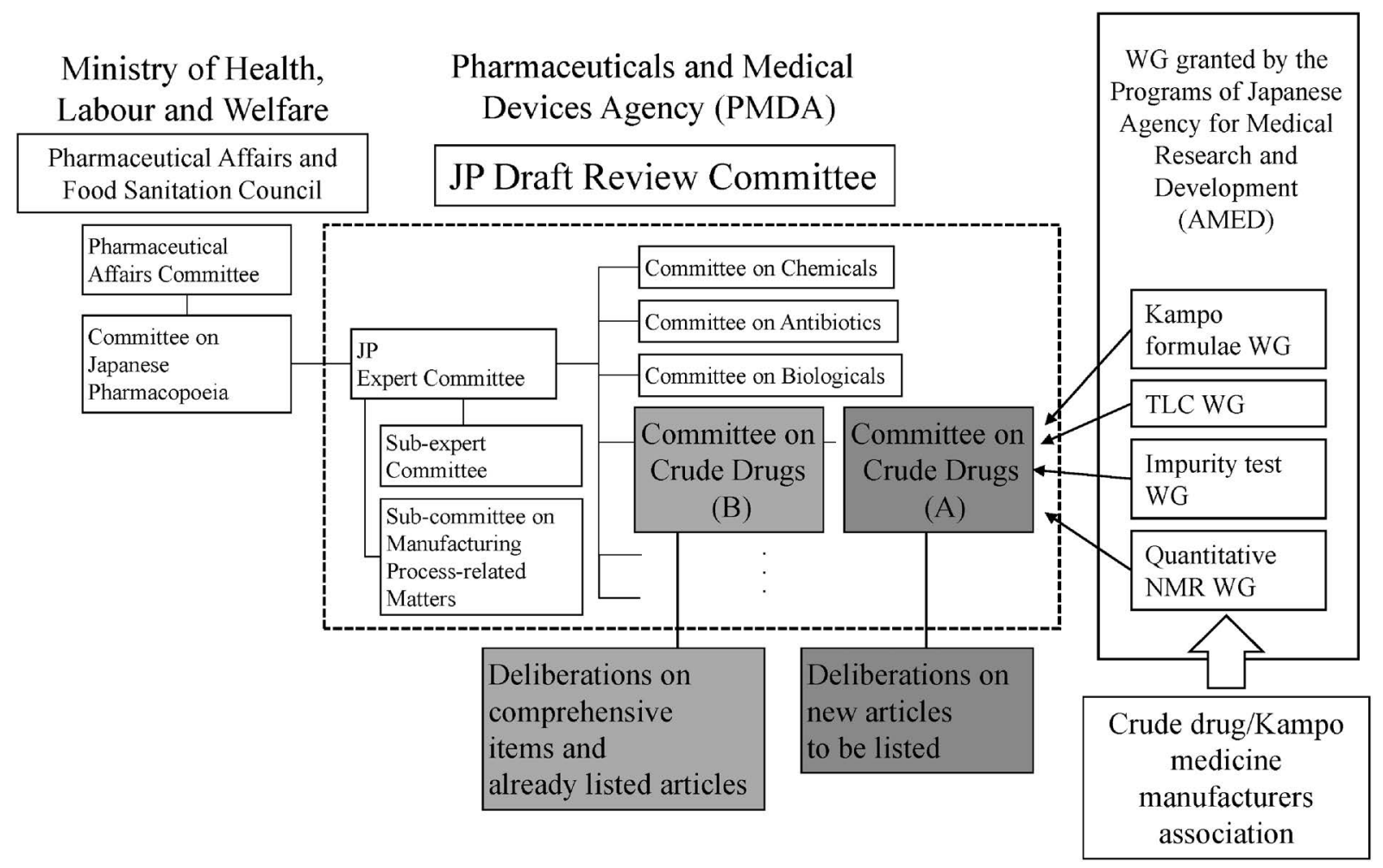

Fig. 3. Organization of the JP Draft Review Committee

の基原植物を使用することもあり，また，製剤にお ける生薬の配合割合は概ね異なり，配合する生薬の 種類が変化している場合もある。このような東アジ ア伝統医学の国際的な多様性が，日局の原案作成過 程に直接的な影響を及ぼすことはほとんどないが, 漢方製剂の原料となる生薬の 8 割が中国からの輸入 に依存していることを勘案して，中国における流通 状況や使用方法についての調査結果を生薬等委員会 や研究班・ワーキンググループ（WG）における参 考資料とし，現状に即した日局原案が作成されるよ う十分に留意されている.

\section{3. 天然物医薬品の日局における標準化の方法}

\section{3-1. 天然物医薬品を日局にて標準化する組織}

現在の日局改正に係る審議体制は，厚生労働省薬 事・食品審議会の日本薬局方部会と医薬品医療機器 総合機構の日本薬局方原案検討委員会により構成さ れている（Fig. 3)。原案検討委員会には様々な専 門性を持つ委員会が設置され，生薬，漢方製剤，生 薬製剂等の日局収載に関する検討は生薬等委員会が 担当する，生薬等委員会はさらに，新規収載品目に 係る事項を主に扱う生薬等（A）委員会と，既収載 品目の改正及び生薬総則や一般試験法等の生薬全体
に関する方針等を扱う生薬等（B）委員会に分かれ ている。ささらに，日本医療研究開発機構（Japan Agency for Medical Research and Development; AMED）の医療研究開発推進事業費補助金補助事 業の一環として，原案検討委員会の枠外にいくつか の研究班・WG が組織され，それぞれの専門性に 基づき生薬等委員会に提案する素案の検討が行われ ている.この研究班・WG として, 漢方処方エキ スの収載原案について検討する「漢方処方 WG」, 確認試験や純度試験における TLC 試験について検 討する「TLC 試験法研究班」, 純度試験における重 金属試験について主に検討する「不純物試験法研究 班」，定量 NMR を用いた定量用試薬・試液の規格 設定等について検討する「定量 NMR 研究班」等が 設置されている。煺の生薬等委員会及び研究班・ WG は, 大学, 研究機関, 産業界の専門家により 構成され，業界団体における専門委員会と緊密に連 携しつつ日局の原案作成に向けて検討が進められて (る. ${ }^{3,4)}$

3-2. 日局における天然物医薬品標準化のプロセ ス一般に, 化学医薬品等の日局新規収載は, 先 発品の再審査が終了し，有効性・安全性の評価が定 


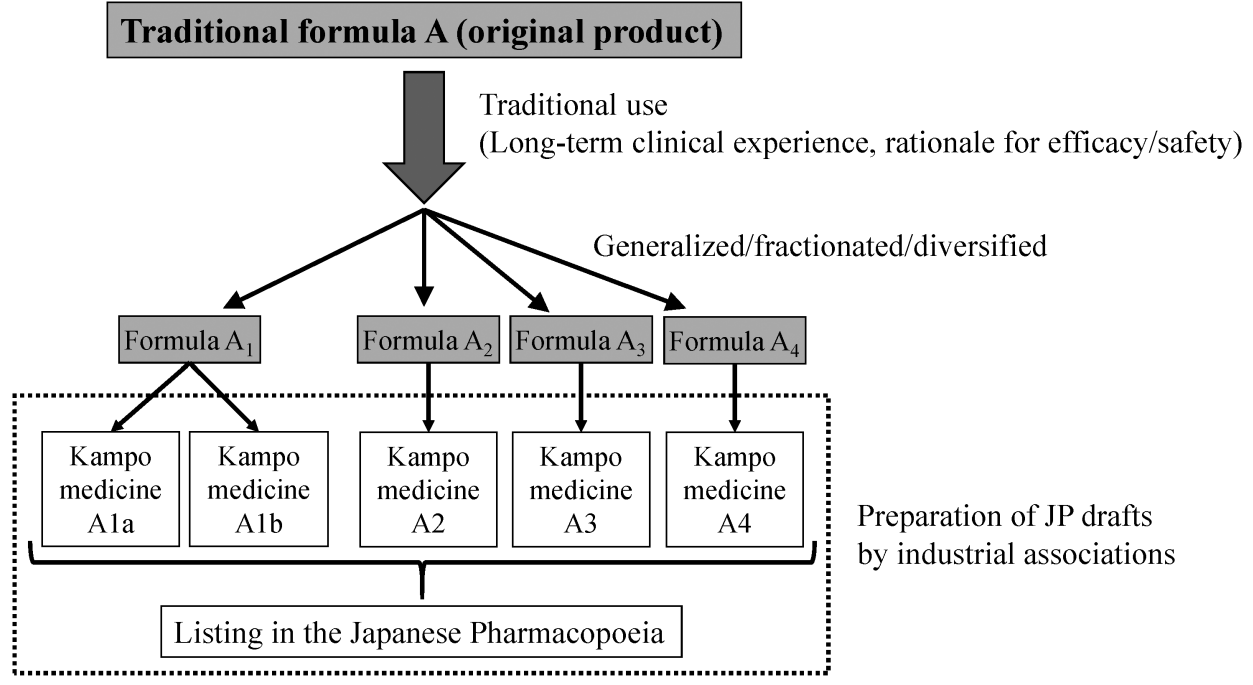

Comprehensive standardization of diversified Kampo products in the JP

Fig. 4. General Process of Preparing the Drafts of New Monographs in the JP for Kampo Medicines

まった状況で開始され，ほとんどの場合，先発品 メーカーを中心として収載原案が作成される，化学 医薬品等における医薬品各条の作成過程は, 先発医 薬品に固有の規格を標準として，わが国の医薬品市 場にその規格を普遍化させる過程と言える。一方， 2-3. で述べたように，伝統的医薬品としての漢方製 剂は，数百年の歴史の中で既に国内で普遍化し，ま た，諸派独自の発展により多様化している，国民の 共有財産である漢方医学に基づくため，特定の処方 が特定のメーカーに独占されるわけではなく，さら に，少しずつ配合割合の異なる処方は，それぞれが 長年の使用経験により安全性と有効性を担保され, それぞれが国により薬事承認されているため，どれ か 1 つの配合割合に統一的に標準化することは難し い.そこで，漢方製剤の日局収載においては，市場 実態を可能な限り反映させるべく, 包括的に標準化 する作業が進められる（Fig. 4)。このため，特定 のメーカーが主導して収載原案を作成するのではな く，業界団体が作成する形となる．結果として，例 えば葛根湯であれば，Table 1 に示す 4 種類の処方 が医薬品各条に規定されている.

なお，最終製剤としての漢方製剤は，各メーカー が用いる賦形剤等の多様性も考慮すると，さらに標 準化が困難となることから，中間製剤である漢方処 方エキスが日局に収載することとされた．漢方処方 エキスの各条は，原則的に，1日量当たりの指標成 分の定量值，製法，性状，構成生薬の確認試験，純
Table 1. Prescriptions of Kakkonto Extract Listed in the Japanese Pharmacopoeia

\begin{tabular}{lllll}
\hline \hline Component crude drugs & $1)$ & $2)$ & $3)$ & $4)$ \\
\hline Pueraria Root & $8 \mathrm{~g}$ & $4 \mathrm{~g}$ & $4 \mathrm{~g}$ & $4 \mathrm{~g}$ \\
Ephedra Herb & $4 \mathrm{~g}$ & $4 \mathrm{~g}$ & $3 \mathrm{~g}$ & $3 \mathrm{~g}$ \\
Jujube & $4 \mathrm{~g}$ & $3 \mathrm{~g}$ & $3 \mathrm{~g}$ & $3 \mathrm{~g}$ \\
Cinnamon Bark & $3 \mathrm{~g}$ & $2 \mathrm{~g}$ & $2 \mathrm{~g}$ & $2 \mathrm{~g}$ \\
Peony Root & $3 \mathrm{~g}$ & $2 \mathrm{~g}$ & $2 \mathrm{~g}$ & $2 \mathrm{~g}$ \\
Glycyrrhiza & $2 \mathrm{~g}$ & $2 \mathrm{~g}$ & $2 \mathrm{~g}$ & $2 \mathrm{~g}$ \\
Ginger & $1 \mathrm{~g}$ & $1 \mathrm{~g}$ & $1 \mathrm{~g}$ & $2 \mathrm{~g}$ \\
\hline
\end{tabular}

度試験（重金属，七素)，乾燥減量，灰分，指標成 分の定量法，貯法で構成されることとされ，定量法 では 1 つの漢方処方エキス当たり 3 つの定量指標成 分の設定が目標とされる.

\section{4. 天然物医薬品を日局で標準化する意義}

日局への収載は，正規な医薬品として公的に認定 されたことを意味し，また，日局の作成方針に明記 されているように，保健医療上重要な医薬品である と認識されたことにほかならない。 また，生薬や漢 方処方エキスが日局において標準化されることは, その生薬や漢方処方エキスの基原や性状が公的に定 義され，また，その品質の規格及びそれを評価する 試験法が公的に示されたことになる。

医薬品の有効性及び安全性を確保するためには品 質保証が重要であり，一定の品質が維持されている 場合にのみ有効性及び安全性を論じることができ る，特に，多成分系で多様性を有する天然物医薬品 
の品質確保には，品質が保証された原料生薬の安定 供給，適切な製造工程の管理，及び原料及び製品の 厳正な品質評価等による多面的・総合的な品質管理 が求められ，この局面で日局が果たす役割は極めて 大きい. ${ }^{5,6)}$

\section{5. まとめ}

第 15 改正において 6 品目の漢方処方エキスが収 載されたことを皮切りに，現行では第 17 改正第二 追補までに 35 品目が収載されている，生産動態上 位の処方から優先的に収載しているため, 医療用漢 方製剤として承認されている 148 処方のうち 35 処 方であっても，医療用漢方製剂の全体の売上額のう ち 7 割以上を既にカバーしている状況である. 日局 において，生薬，漢方製剤，生薬製剂等の品質規格 及び試験法等が公的に標準化されることは，わが国 の天然物医薬品の品質確保における基盤であり，今 後も引き続き最新の科学技術を取り入れつつ, 適切
に改正が進められることを期待する.

利益相反＼cjkstart開示すべき利益相反はない.

\section{REFERENCES}

1) Hakamatsuka T., Pharm Tech Japan, 35, 8392 (2019).

2) Goda Y., Pharmaceutical and Medical Device Regulatory Science, 48, 670-682 (2017).

3) Hakamatsuka T., Pharm Tech Japan, 31, 8794 (2015).

4) Hakamatsuka T., Farumashia, 47, 413-418 (2011).

5) Hakamatsuka T., Yakugaku Zasshi, 137, 163165 (2017).

6) Arai I., Kawahara N., Tradit. Kampo Med., 6, 3-11 (2019). 